\title{
Pemasangan Arrester Multi Chamber Untuk Mengatasi Gangguan Surja Petir di Penyulang Pecatu
}

\author{
I Gede Gerry Julius Perdana ${ }^{1}$, I Gede Dyana Arjana ${ }^{2}$, I Wayan Arta Wijaya ${ }^{3}$
}

\begin{abstract}
Pecatu feeder is a feeder that has a radial distribution system configuration, the length of the line is $31 \mathrm{kms}$. In addition, these feeders have as many as 105 pieces of distribution transformers with a total number of subscribers reached 11,800 subscribers. To protect the feeder from lightning surge interference, then Arrester Multi Chamber are installed on each goalpost to the distribution network to protect the distribution channel in Pecatu feeder. This research is an analisys about installation of Multi Chamber Arrester ini Pecatu Feeder with purpose, how to knows about technical data and performance from Installation of Multi Chamber Arrester at along of distrubtion line of Pecatu Feeder and knows the disturbance data caused by the lightning strike. By placing the arrester approximately 200 meters in every four to five poles, Obtained a voltage increase when experiencing lightning surge with wave speed 4/10 $\mu \mathrm{s}$, with time to peak $10 \mu \mathrm{s}$. Whereas with a $65 \mathrm{kA}$ current flow of 4,147.1831 kV, while for a $20 \mathrm{kA}$ surge current with a placement of arresters on each distribution line, the wave velocity and the time to the same peak are $713,385827 \mathrm{kV}$.
\end{abstract}

Intisari-Penyulang Pecatu merupakan penyulang yang memiliki konfigurasi sistem distribusi tipe radial, dengan panjang saluran $31 \mathrm{kms}$. Selain itu, penyulang ini memiliki trafo distribusi sebanyak 105 buah dengan total jumlah pelanggan mencapai 11.800 pelanggan. Untuk melindungi penyulang dari gangguan surja petir, maka dipasang Arrester Multi Chamber tiap satu tiang pada saluran distribusi untuk melindungi saluran distribusi pada Penyulang Pecatu. Pemasangan Arrester Multi Chamber di penyulang Pecatu dengan tujuan, yaitu mengetahui bagaimana data teknis dan kinerja dari pemasangan Arrester Multi Chamber di sepanjang jaringan distribusi di penyulang Pecatu dan mengetahui data gangguan yang ditimbulkan oleh sambaran petir. Dengan penempatan arrester sekitar berjarak 200 m di setiap empat sampai lima tiang, diperoleh kenaikan tegangan saat mengalami surja petir dengan kecepatan gelombang 4/10 $\mu \mathrm{s}$, dengan waktu sampai kepuncak $10 \mu \mathrm{s}$, dimana dengan arus surja $65 \mathrm{kA}$ yaitu 4.147,1831 kV, sedangkan untuk arus surja $20 \mathrm{kA}$ dengan penempatan arrester pada tiap gawang saluran distribusi, kecepatan gelombang dan waktu sampai ke puncak yang sama didapatkan kenaikan tegangan yaitu $713,385827 \mathrm{kV}$

Kata Kunci:Arrester Multi Chamber, Panjang Penyulang, Penempatan Arrester

\section{PENDAHULUAN}

Pada zaman globlisasi ini, listrik sangat dibutuhkan oleh masyarakat umum. Karena energi listrik yang dibutuhkan

${ }^{\mathrm{T}}$ Mahasiswa, Jurusan Teknik Elektro dan Komputer Fakultas Teknik Universitas Udayana, BTN Dalung Indah Blok F12, Dalung, Kuta Utara, Badung 80361 INDONESIA (tlp: 082147551549; $e$ mail:juliusperdanaa@gmail.com)

${ }^{2,3}$ Dosen, Jurusan Teknik Elektro dan Komputer Fakultas Teknik Universitas Udayana, Jln. Kampus Bukit Jimbaran 80361 'NDONESIA (telp: 0361-703315; fax: 0361-4321; email:.1dyana.arjana@unud.ac.id, ${ }^{2}$ artawijaya@ee.unud.ac.id,) haruslah memiliki kualitas yang baik, serta permintaan kebutuhan energi listrik yang terus meningkat[1] . Di Area Bali Selatan khususnya di Penyulang Pecatu,merupakan sistem distribusi tegangan menengah $20 \mathrm{kV}$ yang mendapat suplai daya dari Gardu Induk Nusa Dua Trafo III/ 60 MVA . Di penyulang Pecatu terdapat beberapa pada tiang SUTM terdapatlah arrester yang merupakan sistem proteksi pada sistem distribusi untuk melindungi dari surja petir. Lightning Arrester di penyulang Pecatu sebelumnya mengalami kegagalan dalam proteksi , karena di Pecatu daerahnya tinggi dan tanah nya mengandung kapur, sehingga resitivitas pada tanah melebihi batas yang diharapkan dan arrester pun terkadang tak mampu mengalirkan listrik ke tanah atau grounding[11].

Gangguan petir adalah gejala tegangan berlebih yang disebabkan oleh arus sambaran petir. Tegangan berlebih maksudnya adalah tegangan yang memiliki amplitudo yang sangat besar dan berlangsung sangat singkat. Tegangan berlebih menyebabkan peralatan isolasi dan komponen dalam sistem tenaga listrik, jika tegangan melebihi BIL (Basic Insulation Level) peralatan isolasi serta komponen sistem tenaga listrik yang digunakan. Arus petir pada saluran distribusi dapat berupa sambaran langsung dan tak langsung yang menyebabkan saluran distribusi terganggu dalam menghantarkan listrik [2].Apabila arus listrik yang mengalir pada isolator saluran lebih besar atau sama dengan tegangan critical flashover maka akan terjadi breakdown sehingga akan mengakibatkan trip pada saluran distribusi.

Berdasarkan hal ini, adapun pemasangan arrester teknologi baru di PT PLN (Persero) Area Bali Selatan yang dilakukan di penyulang Pecatu. Inovasi baru pada teknologi arester telah dibuat oleh penampilan Arrester Multi Chamber. Arrester jenis ini memiliki prinsip dasar yang sama dengan teknologi sebelumnya yang menggunakan celah udara dan tekanan udara. MCA memiliki fungsi untuk melindungi saluran udara dari surja petir. Misalnya, $20 \mathrm{kV}$ saluran udara , pengujian lapangan telah dibentuk untuk mendapatkan analisis tentang Arrester Multi Chamber . pengujian arrester telah dilakukan pada saluran udara tegangan menengah $20 \mathrm{kV}$ dari Penyulang Pecatu.

\section{ARRESTER MULTI CHAMBER SEBAGAI PENANGKAP SAMBARAN PETIR \\ A. Lightning Arrester \\ Lightning arrester adalah suatu alat untuk melindungi isolasi atau peralatam listrik terhadap tegangan lebihyang disebabkan sambaran petir atau tegangan transient yang tinggi dari suatupenyambungan atau pemutusan rangkaian (sirkuit), dengan jalan mengalirkan arus surja (Surge Current) ketanah serta membatasi berlangsungnya arus ikutan (Follow}


Current) serta mengembalikan keadaan jaringan ke keadaan semula tanpa mengganggu sistem[5].

Lightning arrestersebagai pelindung peralatan listrik terhadap tegangan lebih akibat surja petir dan surja hubung serta mengalirkan arus ke tanah. Lightning arrester dilengkapi dengan:

\section{a. Sela bola api (Spark gap) \\ b. Tahanan kran atau tahanan tidak linier (valve resistor)}

c. Sistem pengaturan atau pembagian tegangan (grading system)

Beberapa jenis lightning arrester, antara lain:

a) Type expulsion : terdiri dari dua elektroda dan satu fibre tube. Tabung fibre menghasilkan gas saat terjadi busur api dan menghembuskan busur api kearah bawah. Setelah busur hilang maka arrester bersifat isolator kembali. Jenis lightning arrester tabung ledak (expulsion) ini mempunyai pengaman yang lebih baik, khususnya pada saluran yang mempunyai tingkat gangguan yang rendah[5].

b) Type Valve: bila tegangan surja petir menyambar jaringan dan dimana terdapat lightning arrester terpasang maka seri gap akan mengalami kegagalan mengakibatkan terjadi arus yang besar melalui tahanan kran yang saat itu mempunyai nilai kecil. Bila tegangan telah normal kembali maka tahanan kran mempunyai nilai besar sehingga busur api akan padam pada saat tegangan susulan sama dengan nol[5].

\section{B. Analisa Kerja Arrester}

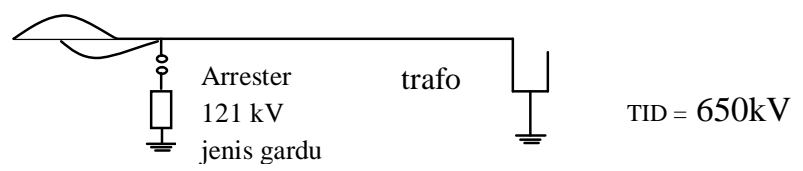

\section{Gambar 1. Skema Sederhana Arrester}

Sambaran petir yang menyambar saluran dapat menimbulkan gelombang berjalan pada kawat saluran. Rambatan surja terdiri dari surja tegangan dan surja arus dengan kecepatan yang bergantung pada konstanta-konstanta kawat[5]. Pada saat surja mencapai titik peralihan akan terjadi kenaikan pada gelombang tersebut sehingga terdapat sedikit perbedaan dengan gelombang asal. Bentuk gelombang berjalan dengan nilai sesaat digambarkan sebagai berikut.

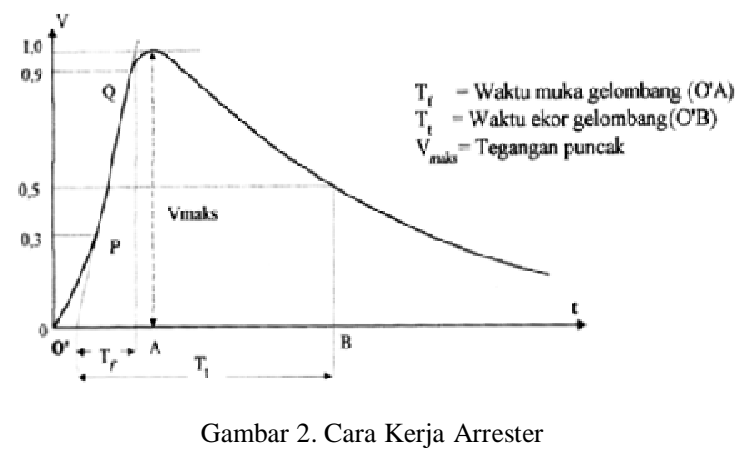

I Gede Gerry Julius Perdana : Pemasangan Arrester Multi ...
Pada saat adanya tegangan lebih pada kawat fasa arrester sudah mulai bekerja pada saat tegangan yang masuk ke arrester sudah mencapai level 0,3 p.u sampai 0,5 p.u . Bila saat melewati angka 0,5p.u arrester belum memotong tegangan lebih maka arrester di katakan gagal. Pada saat gelombang transient melewati tegangan arester maksimum $121 \mathrm{kV}$ 'dengan TID (tingkat isolasi dasar) gelombang penuh $650 \mathrm{kV}$ maka akan dapat merusak peralatan. Untuk itu alat pengaman relay OC (Over Current) dan EF (Earth Faulth) membackup atau mengamankan gelombang transient dengan mengirim perintah trip (lepas) kepada Pemutus Tenaga (PMT) atau Circuit Breaker (CB) dan langsung di tanahkan.

\section{Tegangan Pengenal Arrester}

Tegangan pengenal arrester adalah tegangan saat arrester dapat bekerja sesuai dengan karakteristiknya. Arrester tidak boleh bekerja pada tegangan maksimum sistem, tetapi mampu memutuskan arus susulan dari sistem secara efektif. Arrester umumnya tidak boleh bekerja jika ada gangguan fasa ke tanah, karena tegangan pengenalnya lebih tinggi dari tegangan gangguan fasa ke tanah[11].

Untuk menentukan tegangan maksimum yang mungkin terjadi pada gangguan fasa ke tanah, perlu diketahui :

a. Tegangan maksimum sistem

Umumnya diambil harga $10 \%$ dari harga nominal sistem

b. Koefisien pembumian.

Didefenisikan sebagai perbandingan antara tegangan rms fasa ke tanah, dalam keadaan gangguan pada tempat dimana arrester dipasang dengan tegangan rms fasa ke tanah tertinggi dari sistem dalam keadaan tanpa gangguan.

Untuk sistem yang dibumikan koefisien pembumiannya 0,8 (arrester $80 \%$ ) dan sistem yang tidak dibumikanlangsung koefisien pembumiannya 1,0. Tegangan pengenal dari suatu arrester merupakan tegangan rms fasa ke fasa tertinggi dikalikan dengan koefisien pembumian.

Jika dibumikan langsung :

$$
V_{m}=1,1 \times V_{f n}=1,1 \times V_{\text {nom }} / \sqrt{3}
$$

Jika tidak dibumikan langsung :

$$
V_{m}=V \times 1,10 \times 1,0
$$

\section{D.Tegangan Kerja Arrester}

Tegangan kerja arrester biasa juga disebut tegangan pelepasan atau tegangan sisa, merupakan tegangan yang timbul pada terminal arrester pada saat arus petir mengalir ke $\operatorname{tanah}[11]$.

Tegangan kerja biasa juga disebut tegangan pelepasan atau tegangan sisa, merupakan tegangan yang timbul pada terminal arrester pada saat arus petir mengalir ke tanah. Tegangan kerja arrester tergantung pada kecuraman gelombang arus yang datang.

Pada tabel II merupakan tegangan kerja arrester berdasarkan SPLN 7C, 1978.

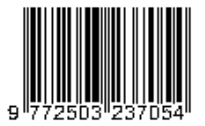


TABEL I

KARAKTERISTIK KERJA ARRESTER UNTUK ARUS 10 KA DAN 5 KA BERDASARKAN SPLN

\begin{tabular}{|c|c|c|c|c|c|}
\hline \multirow{2}{*}{$\begin{array}{c}\text { Rating } \\
\text { Arrester } \\
(\mathbf{k V})\end{array}$} & \multirow{2}{*}{$\begin{array}{c}\text { Kecuraman } \\
\text { FOW } \\
(\mathbf{k V} / \mathbf{\mu} \text { det) }\end{array}$} & \multicolumn{2}{|c|}{$\mathbf{1 0}$ kA dan 5 kA } & \multicolumn{2}{|c|}{$\mathbf{5}$ kA } \\
\cline { 3 - 6 } & $\begin{array}{c}\text { STD } \\
(\mathbf{k V})\end{array}$ & $\begin{array}{c}\text { FOW } \\
(\mathbf{k V})\end{array}$ & $\begin{array}{c}\text { STD } \\
(\mathbf{k V})\end{array}$ & $\begin{array}{c}\text { FOW } \\
(\mathbf{k V})\end{array}$ \\
\hline 3 & 25 & 13 & 15 & 13 & 15 \\
4,5 & 37 & 17,5 & 20 & 17,5 & 20 \\
6 & 50 & 22,6 & 26 & 22,6 & 26 \\
7,5 & 62 & 28 & 31 & 28 & 31 \\
\hline 9 & 76 & 32,5 & 38 & 32,5 & 38 \\
2 & 100 & 43 & 50 & 43 & 50 \\
15 & 125 & 54 & 62 & 54 & 62 \\
18 & 150 & 65 & 75 & 65 & 75 \\
21 & 175 & 76 & 88 & 76 & 8 \\
27 & 225 & 97 & 112 & 97 & 112 \\
30 & 250 & 108 & 125 & 108 & 125 \\
33 & 275 & 119 & 137 & 119 & 137 \\
36 & 300 & 130 & 150 & 130 & 150 \\
\hline
\end{tabular}

\section{E. Arrester Multi Chamber}

Arrester Multi Chamber merupakan Arrester teknologi terbaru yang terdiri dari sejumlah besar elektroda dipasang di panjang karet silikon. Lubang dibor antar elektroda dan melalui langkah panjang dan bertindak sebagai ruang luahan atau discharge gas miniatur. Ketika impuls petir tegangan diterapkan ke arrester, itu merusak kesenjangan antara elektroda[2].

Arrester Multi Chamber (MCA) 20 ditujukan untuk perlindungan dari 3-phase saluran udara transmisi listrik AC dari $24 \mathrm{kV}$ tegangan operasi maksimum dengan terbuka dan ditutupi konduktor terhadap petir induksi lebih tegangan dan konsekuensinya dan dirancang untuk beroperasi di luar ruangan pada suhu kamar mulai dari suhu minus $60^{\circ} \mathrm{C}$ untuk positifnya $50^{\circ} \mathrm{C}[2]$.Berikut ini merupakan gambar Arrester Multi Chamber (MCA).
TABEL II

TEGANGAN KERJA ARRESTER

\begin{tabular}{|c|c|c|c|c|}
\hline $\begin{array}{c}\text { Rating Arrester } \\
(\mathbf{k V})\end{array}$ & $\begin{array}{c}10 \mathrm{kA}, \\
\text { Tugas } \\
\text { ringan\&Tugas } \\
\text { Berat } \\
(\mathrm{kV})\end{array}$ & $\begin{array}{l}5 \mathrm{kA} \\
(\mathrm{kV})\end{array}$ & $\begin{array}{r}2,5 \mathrm{kA} \\
(\mathrm{kV})\end{array}$ & $\begin{array}{r}1,5 \mathrm{kA} \\
(\mathrm{kV})\end{array}$ \\
\hline 0,175 & - & - & 2,2 & 2,2 \\
\hline 0,280 & - & - & 2,5 & 2,5 \\
\hline 0,500 & - & - & 3,0 & 3,0 \\
\hline 0,660 & - & - & 5,0 & 5,0 \\
\hline 3 & 13 & 13 & 13 & - \\
\hline 4,5 & 17,5 & 17,5 & 17,5 & \\
\hline 6 & 22,6 & 22,6 & 22,6 & - \\
\hline 7,5 & 27 & 27 & 27 & - \\
\hline 9 & 32,5 & 32,5 & 32,5 & - \\
\hline 10 & 38 & 38 & 38 & - \\
\hline 12 & 43 & 43 & 43 & \\
\hline 15 & 54 & 54 & 54 & - \\
\hline 18 & 65 & 65 & 65 & - \\
\hline 21 & 76 & 76 & 76 & - \\
\hline 24 & 87 & 87 & 87 & - \\
\hline 27 & 97 & 97 & 97 & - \\
\hline 30 & 108 & 108 & 108 & - \\
\hline 33 & 119 & 119 & 119 & - \\
\hline 36 & 130 & 130 & 130 & - \\
\hline 39 & 141 & 141 & - & - \\
\hline & & & & - \\
\hline
\end{tabular}



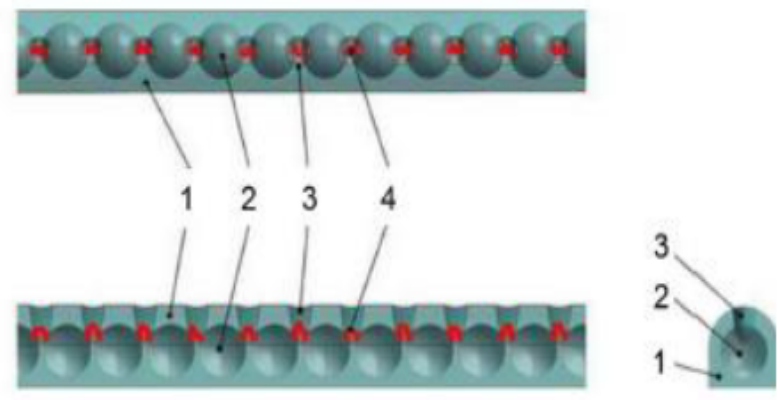

a

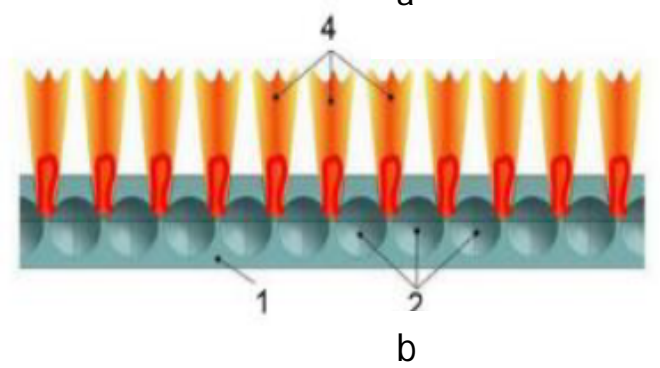

Gambar 3. Sistem kerja pada Arrester Multı Chamber (MCA): (a) Gambar yang menunjukkan debit instan onset. (b) Diagram yang menunjukkan instan debit akhir.

\section{F. Kinerja Arrester Multi Chamber (MCA)}

Kinerja dari pada Arrester Multi Chamber ini terdiri atas spesifikasi berupa tingkatan tegangannya, tipe arrester, kehandalan dalam menahan tegangannya, impuls yang dapat ditangkap ioleh arresternya, massa arrester, dan jangka hidup arrester serta waktu pemeliharaan arrester[8] dapat ditampilkan pada Tabel III berikut ini :

TABEL III KINERJA ARRESTER MULTI CHAMBER (MCA)

\begin{tabular}{|l|l|l|l|l|}
\hline Tingkatan tegangan (kV) & 10 & $10-20$ & 20 & 35 \\
\hline Tipe Arrester - MCA & $10-I^{*}$ & $\begin{array}{l}10- \\
\text { DLS** }\end{array}$ & 20 -DLS & $\begin{array}{l}35- \\
\text { DLS }\end{array}$ \\
\hline $\begin{array}{l}\text { Jumlah ruang pada busur } \\
\text { pendingin kedip }\end{array}$ & 20 & 40 & 120 & 300 \\
\hline $\begin{array}{l}\text { Maksimal 50\%, Impuls } \\
\text { tegangan } \\
\text { flashover ) (kV): } \\
\text { Polaritas Positif (+) } \\
\text { Polaritas Negatif (-) }\end{array}$ & 70 & 85 & 90 & 150 \\
\hline $\begin{array}{l}\text { Minimum menahan } \\
\text { tegangan Frekuensi day } \\
\text { (kV) }\end{array}$ & 70 & 85 & 85 & 120 \\
$\begin{array}{l}\text { Saat dalam kedaan kering } \\
\text { Saat dalam keadaan basah }\end{array}$ & 42 & 65 & 65 & 75 \\
\hline
\end{tabular}

I Gede Gerry Julius Perdana : Pemasangan Arrester Multi ...

\begin{tabular}{|l|l|l|l|l|}
\hline $\begin{array}{l}\text { Minimum besarnya } \\
\text { impuls arus dalam 4/10 } \\
\mu \mathrm{s}, \text { bertahan pada (kA) : }\end{array}$ & 100 & 100 & 100 & 100 \\
$-\quad 2$ aplikasi & 65 & 65 & 65 & 65 \\
$-\quad 0$ aplikasi & 0.2 & 0.6 & 2 & 6 \\
$\begin{array}{l}\text { Massa (Kg) } \\
\begin{array}{l}\text { Minimal jangka waktu } \\
\text { pemeliharaan Arrester } \\
\text { tahun) }\end{array}\end{array}$ & 30 & 30 & 30 & 30 \\
\hline
\end{tabular}

\section{G. Pemasangan Arrester Multi Chamber}

Pemasangan Arrester Multi Chamber ini dilakukan karena , supaya menstabilkan tegangan arus listrik saat terjadi lonjakan sehingga mampu melindungi berbagai peralatan elektronik dari kerusakan akibat lonjakan tengangan surja petir (surge atau tegangan kejut)[2].

Tegangan surja petir ini dapat terjadi akibat adanya putus sambung dari sebuah tenaga listrik yang mempunyai daya yang besar dan akibat dari adanya sambaran petir. Tetapi Arrester Multi Chamber membuang listrik kembali ke udara dan sisanya ke tanah, ini dikarenakan pentanahan di daerah Pecatu sangatlah tinggi melebihi $10 \mathrm{ohm}$. Pada penyulang Pecatu dipasanglah Arrester Multi Chamber sebanyak 50 buah arrester pada tiap gawang[2].

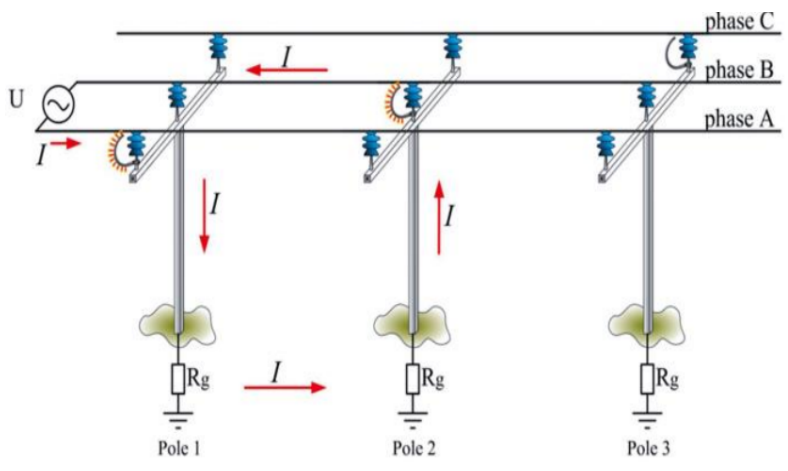

Gambar 4. Struktur Pemasangan Arrester Multi Chamber

Arrester yang terpasang merupakan Arrester induksi tegangan tinggi. Pemasangan pada arrester ini dimaksudkan menjadi salah satu bagian dalanm satu kutub, pada fasa alternatif. Konfigurasi Arrester Multi Chamber ini terutama dimaksudkan untuk bekerja pada tiga pasang sambungan dengan saluran untuk arus dibentuk sebagai kesalan pada pada pembumian ganda atau hubungan arus singkat (short circuit ) yang melalui tanah ( grounding ). Berkat pemasangan dan konfigurasi tersebut, maka tingkat kesalahan sangat berkurang, memungkinkan perangkat yang lebih kecil untuk digunakan[2].

\section{H. Proses Discharge pada Arrester Multi Chamber}

Arrester terdiri atas sejumlah besar elektroda dipasang pada rubber sillicone. Lubang antara elektroda dan akan melalui bagian dari lubang-lubang yang panjang yang berfungsi sebagai ruang miniatur pelepasan impuls arus petir.terdapat 
beberapa tahap-tahap dari proses saat sambaran petir datang menuju Arrester sampai dibuang ke udara[8]. Berikut merupakan prosesnya :

1) Pertama gelombang impuls petir datang menuju perangkat pelindung jaringan terhadap petir, lalu gaps atau lubang celah yang berada diantara elektroda yang bersifat konduktif atau penghantar yang baik itu memecah, sehingga memberikan bagian yang terionisasi di dalam saluran peluahan (discharge channel), untuk menggagalkan prose pembentukan arus petir di dalam ruang (chambers) tersebut[8].

2) Kedua , Pada saluran peluahan ( discharge channel ) itu mengembang dengan meningkatkan nilai arus, yang membuat tekanan tinggi di dalam suatu ruang (chambers) , serta busur listrik yang membentuk bunga api itu terjadi di antara sekat-sekat elektroda di dalam ruang dengan volume yang rendah, maka percikan api pada elektroda berpindah menuju ke permukaan body isolasi karean mengalami tekanan yang sangat tinggi[8].

3) Yang ketiga , pada saat menuju ke permukaan isolasi maka arus yang berbentuk percikan tersebut dibuang lebih jauh disekitar perangkat pelindung jaringan dan tidak mengenai jaringan juga. Di dalam pengaruh proses blowing dan pemanjangan pada saluran diantara elektroda, pendingin intensive langsung mengambil alih dengan meningkatkan resistivitas listrik. Total dari penghambatan pada perangkat tersebut meningkat, mengaktifkan pendinginan dari arus gangguan sebelum bagian pertama melalui nol. Pada proses tersebut secara kondisional disebut zero quenching.

\section{A. Bagian-Bagian dari Arrester Multi Chamber}

Berikut ini terdapat bagian-bagian pada Arrester Multi Chamber [8], berikut adalah keterangannya :

1) Sillicone rubber enclosure merupakan bagian permu] 5 atau tubuh isolasi pada arrester multi chamber : terbuat dari karet silikon.

2) Intermediate electrodes merupakan bagian tengah elektrode yang berfungsi membuat busur listrik dalam elektroda tersebut [8].

3) Arc Quenching Chamber berfungsi sebagai Pendingin busur api yang berada pada ruang-ruang tempat discharge[8].

4) Discharge channel merupakan bagian saluran tempat peluahan atau discharge untuk tempat blow out percikan busur api lalu terjadi pemanjangan pada saluran ini[8].

Multi Chamber System(MCS), yang digunakan dalam MCA20 (Arrester MultiChamber) mencakup sejumlah besar elektroda dipasang secara seri pada bentuk karet silikon (Satu elektroda dengan ruang discharge).Sistem ini membantu untuk membagi listrik yang besar (busur api yang terjadi dalam kasus tegangan lebih petir) di sejumlah besar busur kecil.yang ada di ruang debit peluahan atau dischargeyang cukup kecil yang dibentuk oleh dua elektroda yang berdekatan. Tekanan tinggi muncul di ruang discharge (dengan kombinasi suhu yang sangat tinggi dari busur dan kecil ukuran ruang) menekan busur api keluar ke udara luar dan dengan demikian akan memadamkan busur api (dalam waktu maksimum 10msec)[8]. Berikut ini merupakan gambar mengenai bagian-bagian pada Arrester Multi Chamber:
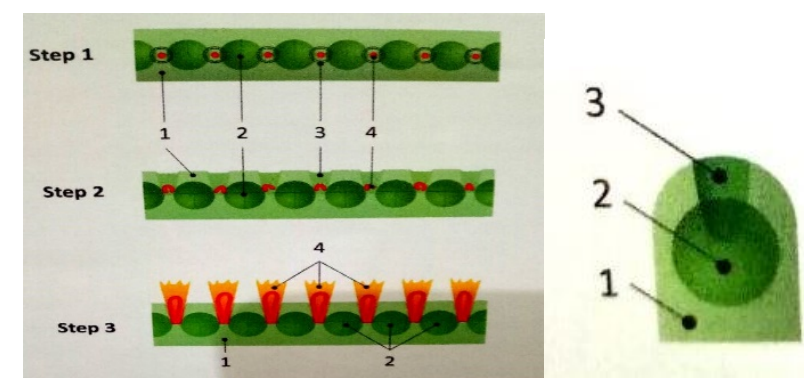

Gambar 5.Proses discharge pada Arrester Multi Chamber

\section{METODE PENELITIAN}

Penelitian ini bertempat di PT. PLN (Persero) Distribusi Bali Area Bali Selatan dengan tujuan memperoleh data-data penunjang untuk penelitian dan waktu pelaksanaannya dimulai pada bulan Juli 2016 sampai dengan November 2016. Penelitian tugas akhir ini menggunakan data sekunder, yang didapat dari PT. PLN (Persero) ) Area Jaringan Bali Selatan, dimana data-data tersebut antara lain :

1. Single line diagram Penyulang Pecatu.

2. Data Teknis pemasangan Arrester Multi Chamber di Penyulang Pecatu.

3. Data gangguan (trip) karena sambaran petir di penyulang Pecatu.

4. Data jenis pada Arrester Multi Chamber di penyulang Pecatu.

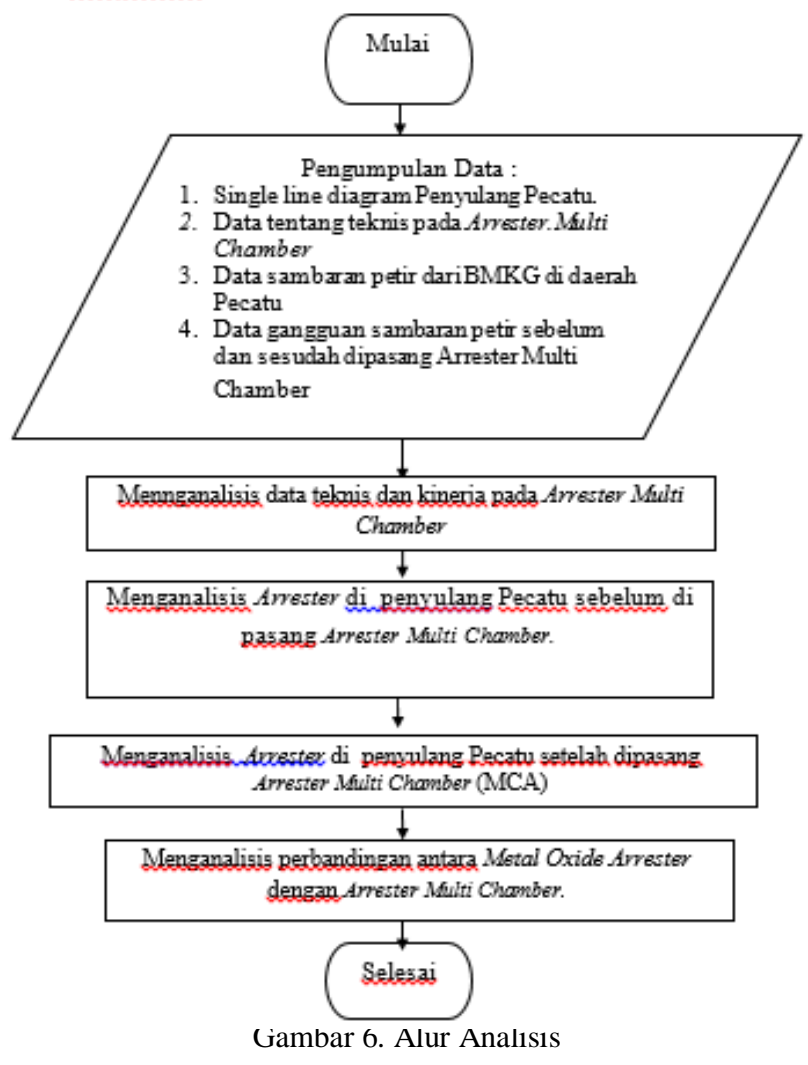

BAB IV HASIL DAN ANALISIS

A. Sistem Distribusi Penyulang Pecatu 
Penyulang Pecatu adalah penyulang yang mendapat suplai tenaga listrik dari GI Nusa DuaTrafo III / 60 MVA yang terletak di wilayah Kuta Selatan.Wilayah operasi yang dilayani adalah daerah Pecatu, Labuan Sait, Suluban , Padang-padang, Goa Lempeh, dan Uluwatu . Penyulang Pecatu merupakan penyulang yang memiliki konfigurasi sistem distribusi tipe radial, dengan panjang saluran $31 \mathrm{kms}$. Selain itu, penyulang ini memiliki trafo distribusi sebanyak 105 buah. Pada daerah Pecatu memiliki proteksi sambaran yang besar, jumlah sambaran maksimum perbulan mencapai lebih dari 6000 sambaran ke tanah Pada tahun 2016 memiliki aktivitas petir yang tinggi dengan gangguan pada penyulang Pecatu sebanyak 7 kali. Berikut data dari PLN Rayon Kuta diperoleh data gangguan petir yang terjadi di wilayah daerah Pecatu periode tahun 2016 dengan Jumlah tiang di penyulang Pecatu adalah 248 , dan yang di ketanahkan 50 tiang setiap 4 gawang yang di ketanahkan. Setiap gawang pun dipasang jarak sejauh 200m dengan dipasang dengan bentu diagonal. Pada gambar dibawah ini merupakan Single Line Diagram pada penyulang Pecatu :

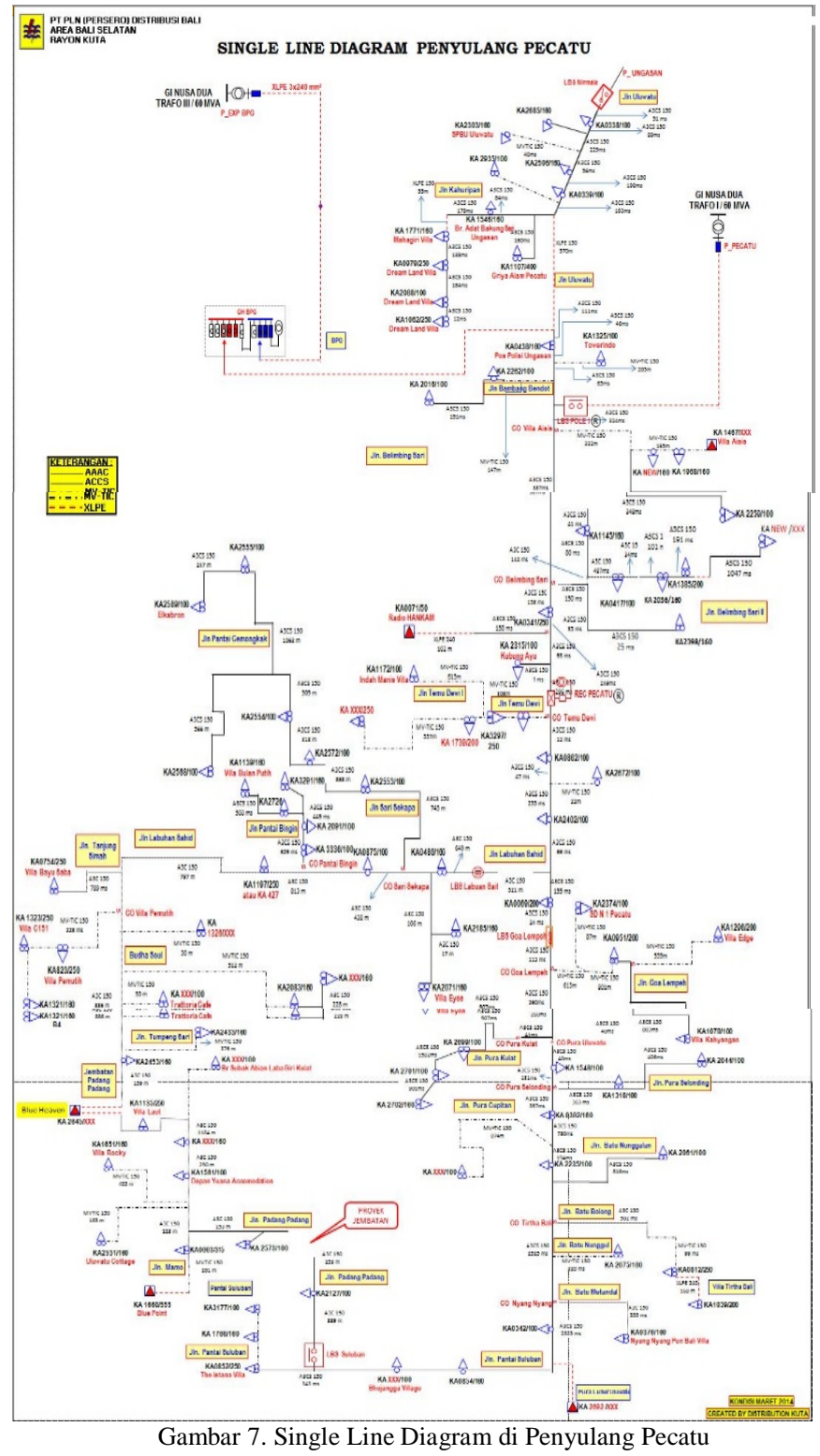

I Gede Gerry Julius Perdana : Pemasangan Arrester Multi ...
B. Gelombang Arus Sambaran Petir di daerah Pecatu

Gelombang arus petir yang menyambar di daerah Bali Selatan berikut ini dianalisis dengan mencari nilai statistik arus puncak petir, karena berguna untuk penentuan konstruksi terminal udara dan spesifikasi arrester. Berikut gambarnya dibawah ini :

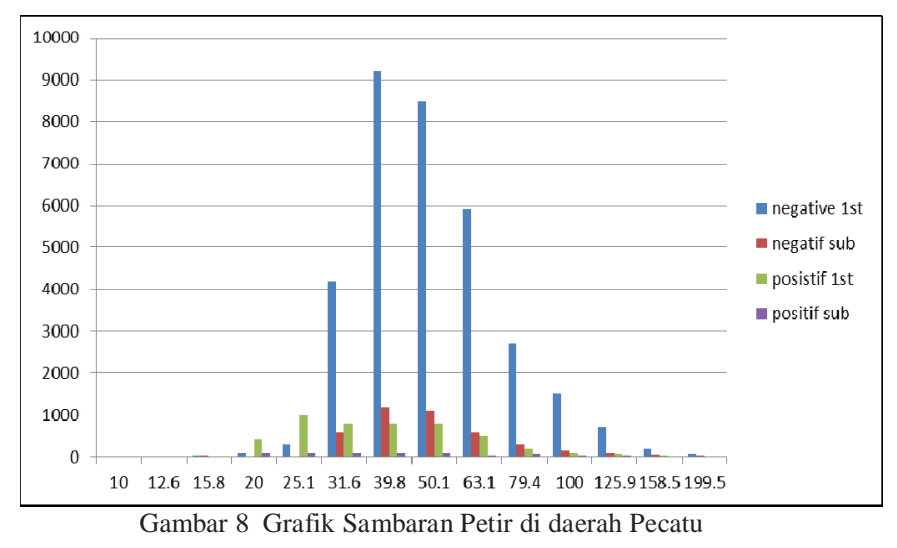

Keterangan :

Negative Fisrt : Sambaran Petir pertama negatif ( merah)

Negative subsequent: sambaran petir susulan negatif (ungu) Positive First : sambaran petir pertama positif ( kuning)

Postive subsequent : Sambaran petir susulan positif ( putih)

Pada grafik di atas merupakan statistik dari nilai arus puncak pada petir. Sistem proteksi petir pada saluran distribusi. Probabilitas arus puncak adalah presentase yang menunjukkan kejadian sambaran petir dengan arus puncak lebih besar dari nilai tertentu. Misal, untuk arus arus x kA, probabibilitasnya y\% . Maksudnya, y\% lebih besar dari x kA . Untuk sistem proteksi saluran udara distribusi tenaga listrik, angka probabilitas yang digunakan yaitu $50 \%$. Pulau Bali mempunyai aktivitas kejadian petir $50 \%$ pada harga sekitar $45 \mathrm{kA}$. Angka arus puncak petir tersebut digunakan secara praktis sebagai dasar perancang sistem proteksi petir di Bali. Pada diagram statistik diatas angka tegangan impuls petir pada daerah tersenbut tertinggi adalah $90 \mathrm{kV}$ dengan arus petir sebesar 39,8 kA.

\section{Perbandingan Antara Metal Oxide Arrester dengan Arrester Multi Chamber}

\section{Perbandingan Dalam Proses Discharge}

Berikut ini merupakan suatu gambar diagram yang menunjukkan perbandingan nilai efisien dan ekonomis antara Lightning Arrester yang biasa disebut juga MOA (Metal Oxide Arrester ) dengan MCA yang ada pada gambar 9. berikut ini: 


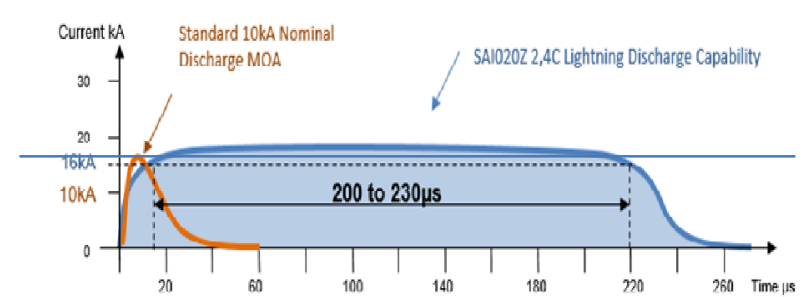

Gambar 9.Diagram Perbandingan Antara Lightning Arrester dengan Arrester Multi Chamber

Dari gambar 9. menunjukkan perbandingan antarakedua arrester tersebut mengenai prinsip kerjanya untuk menangkal arus pada tegangan petir supaya tidak terjadi trip pada saluran distribusi $20 \mathrm{kV}$, Arus petir yang datang menuju saluran distribusi ,ditangkap oleh bagian chambernya dengan maksimum dapat menangkap surja petir sebesar $90 \mathrm{kV}$. Pada grafik tersebut dijelaskan bahwa arus petir dipotong atau mengalami (discharge) dan arus yang masuk adalah sebesar $16 \mathrm{kA}$, dan dapat mendischarge arus sambaran selama 200 $230 \mu \mathrm{S}$. Setelah ditunjukkan grafik hasil dari tes impuls petir maka didapatkan juga lonjakan gelombang petir dikarenakan lebih dari tegangan kerja $90 \mathrm{kV}$. Jadi pada gambar 9 . didapatkan analisis perhitungannya adalah dengan menggunakan rumus yang sama, dapat dihitung kenaikan tegangan pada saluran distribusi saat mengalami surja petir dengan kecepatan gelombang surja $4 / 10 \mu \mathrm{s}$, waktu sampai kepuncak untuk test impuls $4 / 10 \mu$ s adalah sekitar 200- 230 $\mu \mathrm{s}$, , serta besar arus surja $\left(I_{p}\right) 16 \mathrm{kA}$ dan untuk test impuls adalah sebagai berikut :

a. Untuk arus surja $16 \mathrm{kA}$

Vup $\max =\mathrm{L} \frac{d i}{d t}$

Dimana :

Vupmax = Besar kenaikan tegangan pada saluran distribusi $(\mathrm{kV})$

$$
\begin{aligned}
\mathrm{L} \frac{d i}{d t} & =\text { Besar kenaikan tegangan pada kawat } \\
& \text { arrester }(\mathrm{kV}) \\
= & \text { Puncak arus surja }(\mathrm{kA}) \\
= & \text { Waktu sampai mencapai arus puncak surja } \\
I_{p} & (\mu \text { detik) } \\
t_{p} & =\text { Induktansi pada kawat arrester }(0,4 \mu \mathrm{H} / \mathrm{ft}) \\
\mathrm{L} & =
\end{aligned}
$$

Jadi hasil yang didapat adalah :[5]

$$
\begin{aligned}
\text { Vup max }= & \mathrm{L} \frac{d i}{d t}=0,4 \cdot 2,718 \frac{16}{200} \\
& =0,075773491 \mathrm{kV} / \mathrm{ft} \quad= \\
& 0,248600692 \mathrm{kV} / \mathrm{m} \text {, dimana } 1 \mathrm{ft}=0,3048 \mathrm{~m}
\end{aligned}
$$

Jika pemasangan arrester Chamber sebanyak 4 gawang ( 1 gawang $=50 \mathrm{~m}$ )maka kenaikan tegangan pada saluran distribusi adalah :

$$
\begin{array}{ll}
\text { Vup max } & =0,248600692 \times 200 \mathrm{~m} \\
& =4,61915195 \mathrm{kV}
\end{array}
$$

\section{Pemilihan Arrester Multi Chamber Sebagai Pelindung Petir}

\section{Tegangan pengenal arrester(ratting arrester)}

Tegangan pengenal arrester merupakan tegangan rms fasa ke fasa tertinggi dikalikan dengan koefisien pembumian. Dalam hal ini dikategorikan pembumian langsung maka[13]:

- Tegangan sistem maksimum

$$
\begin{aligned}
& =\mathrm{V}_{\text {nominal }}+10 \% \text { (faktor toleransi) } \\
& =20 \mathrm{kV}+(20 \times 10 \%) \\
& =(20+2) \mathrm{kV} \\
& =22 \mathrm{kV}
\end{aligned}
$$

- $\quad$ Tegangan pengenal arrester

$$
=22 \mathrm{kV} / \sqrt{3} \text { (3fasa) }=13 \mathrm{kV}
$$

b. Menentukan tegangan terminal arrester

Arrester yang digunakan mempunyai tegangan pengenal $24 \mathrm{kV}$ dengan kecuraman surja (dv/dt) adalah $200 \mathrm{kV} / \mu$ detik.

Jadi kecepatan naiknya tegangan surja adalah :

$$
\begin{aligned}
& =\frac{200 k V / \mu \operatorname{det} i k}{24 k V} \\
& =8,33 \mathrm{kV} / \mu \text { detik }
\end{aligned}
$$

Dari karakteristik, didapat tegangan sela gagal $=3,6 \mathrm{kV} / \mu$ detik tiap $\mathrm{kV}$ rating maka :

Tegangan terminal arrester $=$ tegangan sela gagal $\mathrm{x}$ tegangan pengenal

$\mathrm{V}=3,6 \times 24=86,4 \mathrm{kV}$

2. Menentukan tegangan percikan impuls maksimum

Untuk menentukan besar tegangan percikan impuls maksimum dengan tegangan pengenal arrester $24 \mathrm{kV}$, maka dengan menggunakan tabel karakteristik arrester diperoleh tegangan percikan impuls maksimum sebesar $87 \mathrm{kV}$.

3. Menentukan Tegangan Kerja Arrester

Untuk menentukan tegangan kerja arrester digunakan tabel ini diperoleh tegangan kerja arrester sebesar $87 \mathrm{kV}$. Dari hasil itu di peroleh arrester maksimum mampu memotong tegangan surja sebesar $87 \mathrm{kV}$.

4. Menentukan Faktor Perlindungan

Sebelum menentukan faktor perlindungan, terlebih dahulu harus menentukan tingkat perlindungan (TP) yang diberikan arrester terhadap peralatan yang dilindungi. Tingkat perlindungan dapat ditentukan menggunakan rumus sebagai berikut :

$$
\begin{aligned}
& \mathrm{TP}=V_{a}+10 \% V_{a} \\
& \mathrm{TP}=V_{a} \times 1,1
\end{aligned}
$$

Dari rumus tersebut, dapat dihitung tingkat perlindungan dari arrester dengan tegangan pengenal $24 \mathrm{kV}$ dengan kelas arus $10 \mathrm{kA}$, dimana dari tabel karakteristik Metal Oxide Arrester didapatkan besar dari $V_{a}$ ( tegangan terminal ) adalah $87 \mathrm{kV}$, maka tingkat perlindungannya adalah :

$\mathrm{TP}=87 \times 1,1$

$\mathrm{TP}=95,7 \mathrm{kV}$

Keterangan : TP = Tegangan Pengenal

Kemudian faktor perlindungan dapat dihitung dengan rumus sebagai berikut ; 
$\mathrm{FP}=\frac{T_{\text {trafo }}-T P}{\text { TID }_{\text {trafo }}} \times 100 \%$

Dari rumus diatas, dapat dihitung faktor perlindungan dari peralatan dengan TID yaitu $125 \mathrm{kV}$, yaitu:

$\mathrm{FP}=\frac{125-95,7}{125} \mathrm{x} 100 \%=23,44 \%$

Dari perhitungan tersebut, faktor perlindungan yang diperoleh adalah $23,44 \%$ dari $20 \%$ dari BIL peralatan pada umumnya, sehingga pemilihan arrester sudah dapat memberikan faktor perlindungan yang baik.

G. Perhitungan Kenaikan Tegangan pada Saluran Distribusi

Akibat Surja Petir dengan Kecepatan Gelombang Surja 4/10 $\mu$ s dan $8 / 20 \mu$ s

Sebelum menghitung kenaikan tegangan saluran distribusi pada penyulang Pecatu akibat surja petir, maka perlu diketahui terlebih dahulu kecepatan gelombang surja serta besar arus surja yang terjadi di penyulang Pecatu , Bali Selatan.

Dengan menggunakan rumus yang sama, dapat dihitung kenaikan tegangan pada saluran distribusi saat mengalami surja petir dengan kecepatan gelombang arus surja $65 \mathrm{kA}$ $4 / 10 \mu \mathrm{s}$, serta besar arus surja $\left(I_{p}\right) 20 \mathrm{kA}$ untuk test impuls $8 / 20 \mu$ s sebagai berikut :

a.Untuk arus surja $65 \mathrm{kA}$

$$
\text { Vupmax }=\mathrm{L} \frac{d i}{d t}=0,4.2,718 \frac{65}{10}
$$

$=7,0668 \mathrm{kV} / \mathrm{ft}$

$=20,73591549 \mathrm{kV} / \mathrm{m}$, dimana $1 \mathrm{ft}=0,3048 \mathrm{~m}$

Jika jarak pemasangan arrester distribusi sepanjang , maka kenaikan tegangan pada trafo distribusi adalah :

$$
\begin{aligned}
& =20,73591549 \times 200 \mathrm{~m} \\
& =4.147,1831 \mathrm{kV}
\end{aligned}
$$

Jika jarak pemasangan arrester Chamber maka kenaikan tegangan pada saluran distribusi adalah :

b. Untuk arus surja $20 \mathrm{kA}$ dengan tes impuls 8/20Vupmax $=\mathrm{L}$

$\frac{d i}{d t}=0,4.2,718 \frac{20}{20}$

$=1,0872 \mathrm{kV} / \mathrm{ft}$

$\mathrm{m}$

$$
=3,566929134 \mathrm{kV} / \mathrm{m} \text {, dimana } 1 \mathrm{ft}=0,3048
$$

Jika jarak pemasangan arrester distribusi sepanjang , maka tegangan kerja pada saluran distribusi adalah :

$$
\begin{aligned}
& =3,566929134 \times 200 \mathrm{~m} \\
& =713,385827 \mathrm{kV}
\end{aligned}
$$

H. Pemilihan Metal Oxide Arrester Sebagai Pelindung Petir

\section{Tegangan pengenal Arrester pada Metal Oxide Arrester} (ratting arrester)

- Tegangan sistem maksimum

$$
\begin{aligned}
& =\mathrm{V}_{\text {nominal }} \times 10 \% \text { (faktor toleransi) } \\
& =20 \mathrm{kV} \times 1,1 \\
& =22 \mathrm{kV}
\end{aligned}
$$

- Tegangan pengenal arrester

$$
=24 \mathrm{kV} / \sqrt{3} \text { (3fasa) }=13 \mathrm{kV}
$$

I Gede Gerry Julius Perdana : Pemasangan Arrester Multi ...
2.. Menentukan tegangan terminal arrester

Arrester yang digunakan mempunyai tegangan pengenal $24 \mathrm{kV}$ dengan kecuraman surja (dv/dt) dari tabel 2.2 adalah $200 \mathrm{kV} / \mu$ detik.

Jadi kecepatan naiknya tegangan surja adalah :

$$
\begin{aligned}
& =\frac{200 k V / \mu \operatorname{det} i k}{24 k V} \\
& =8,33 \mathrm{kV} / \mu \text { detik }
\end{aligned}
$$

Dari karakteristik, didapat tegangan sela gagal $=3,6 \mathrm{kV} / \mu$ detik/kV rating maka :

Tegangan terminal arrester $=$ tegangan sela gagal $\mathrm{x}$ tegangan pengenal

$\mathrm{V}=3,6 \times 24=86,4 \mathrm{~K}$

TABEL IV

PERHITUNGAN TEGANGAN TERMINAL LIGHTNING ARRESTER

\begin{tabular}{|c|c|c|c|c|c|}
\hline No & $\begin{array}{c}\text { Teg. } \\
\text { Kerja } \\
\text { Arrester }\end{array}$ & $\begin{array}{c}\text { Kecuraman } \\
(\mathbf{k V / \mu s )}\end{array}$ & $\begin{array}{c}\text { Teg. } \\
\text { Sela } \\
\mathbf{G a g a l} \\
(\mathbf{k V})\end{array}$ & $\begin{array}{c}\text { Kec. Naik } \\
\text { teg. Surja } \\
(\mathbf{k V} / \mathbf{\mu s})\end{array}$ & $\begin{array}{c}\text { Teg. } \\
\text { Terminal } \\
\mathbf{L A}\end{array}$ \\
\hline 1 & 18 & 150 & 3,6 & 8,333333 & 64,8 \\
\hline 2 & 21 & 175 & 3,6 & 8,333333 & 75,6 \\
\hline 3 & 24 & 200 & 3,6 & 8,333333 & 86,4 \\
\hline
\end{tabular}

3. Menentukan tegangan percikan impuls maksimum

Untuk menentukan besar tegangan percikan impuls maksimum dengan tegangan pengenal arrester $24 \mathrm{kV}$, maka dengan tabel di bawah ini pada arrester diperoleh tegangan percikan impuls maksimum sebesar $100 \mathrm{kV}$.

TABEL V

TEGANGAN MAKSIMUM SPARKING IMPULS

\begin{tabular}{|c|c|c|}
\hline No & $\begin{array}{c}\text { Tegangan } \\
\text { Pengenal LA }\end{array}$ & Tegangan Impuls max \\
\hline 1 & 18 & 75 \\
\hline 2 & 21 & 88 \\
\hline 3 & 24 & 100 \\
\hline
\end{tabular}

d. 4. Menentukan Tegangan Kerja Arrester

Untuk menentukan tegangan kerja arrester dari tabel di bawah ini diperoleh tegangan kerja arrester sebesar $87 \mathrm{kV}$.

TABEL VI

TEGANGAN KERJA PADA LIGHTNING ARRESTER ( METAL OXIDE ARRESTER )

\begin{tabular}{|c|c|c|}
\hline No & Tegangan Pengenal LA & Tegangan Kerja LA \\
\hline 1 & 18 & 65 \\
\hline 2 & 21 & 76 \\
\hline 3 & 24 & 87 \\
\hline
\end{tabular}


Dari hasil perhitungan kerja arrester, rating arrester $24 \mathrm{kV}$ mempunyai tegangan puncak maksimum sebesar 175 $\mathrm{kV}$ dan dari hasil itu di peroleh arrester sudah mulai bekerja pada saat tegangan impuls petir pada saat mencapai tegangan $87 \mathrm{kV}$ kemudian arrester sudah memulai memotong tegangan impuls petir tesebut pada saat mencapai tegangan $87 \mathrm{kV}$.

5. Menentukan Arus Pelepasan Arrester

a. Menentukan Tegangan Puncak Surja

Tegangan lompatan api impuls (TID saluran) yang 9 diambil adalah $125 \mathrm{kV}[13]$, maka :

$\mathrm{V}_{\text {puncak }}=1,2 \times$ TID (tingkat isolasi impuls dasar) saluran

$$
=1,2 \times 125 \mathrm{kV}
$$$$
=150 \mathrm{kV}
$$

b. Menentukan Arus Pelepasan Arrester

Arus pelepasan arrester digunakan untuk menentukan kelas arrester. Arus pelepasan nominal arrester yang diperoleh adalah :

$$
I_{a}=\frac{2 V_{\text {puncak }}-V \alpha}{Z_{s}}=\frac{2 x 150-86,4}{448,987}=0,475
$$

$\mathrm{kA}$

Dari hasil ini, untuk daerah yang mempunyai frekuensii sambaran petir yang tinggi dan kemungkinan arus surja dengan puncak yang tinggi maka kelas arus arrester $10 \mathrm{kA}, 5$ kA tidak relevan digunakan. Karena apabila terkena sambaran petir yang kuat dan terus menerus, arrester yang lebih kecil kemungkinan akan mengalami kegagalan sehingga tidak dapat melindungi saluran

TABEL VII

ARUS PELEPASAN LIGHTNING ARRESTER

\begin{tabular}{|c|c|c|c|c|c|}
\hline No & $\begin{array}{c}\text { Teg. } \\
\text { Kerja } \\
\text { Arreste } \\
\mathbf{r}\end{array}$ & $\begin{array}{c}\text { Teg. } \\
\text { Termina } \\
\mathbf{I} \text { LA } \\
(\mathbf{k V})\end{array}$ & $\begin{array}{c}\text { Teg. } \\
\text { Puncak } \\
\text { Surja (kV) }\end{array}$ & $\begin{array}{c}\text { Arus } \\
\text { Pelepasan } \\
(\mathbf{A})\end{array}$ & $\begin{array}{c}\text { Kelas LA } \\
(\mathbf{k A})\end{array}$ \\
\hline 1 & 18 & 64,8 & 150 & 523,8459 & 5 \\
\hline 2 & 21 & 75,6 & 150 & 499,79175 & 5 \\
\hline 3 & 24 & 86,4 & 150 & 475,75562 & 5 \\
\hline
\end{tabular}

c. Menentukan Faktor Perlindungan

Dalam menentukan faktor perlindungan, maka yang pertama-tama dihitung adalah tingkat perlindungan arrester yaitu:

TABEL VIII

FAKTOR PERLINDUNGAN ARRESTER

Berikut ini adalah tabel mengenai faktor perlindungan

Arrester pada sistem distribusi di Penyulang Pecatu

\begin{tabular}{|c|c|c|c|c|}
\hline No & $\begin{array}{c}\text { Teg. Kerja } \\
\text { Arrester }\end{array}$ & $\begin{array}{c}\text { Sparking } \\
\text { Voltage } \\
(\mathrm{kV})\end{array}$ & $\begin{array}{c}\text { Tingkat } \\
\text { Lindung LA } \\
(\mathrm{kV})\end{array}$ & $\begin{array}{c}\text { Faktor } \\
\text { Lindung } \\
(\%)\end{array}$ \\
\hline 1 & 18 & 65 & 71,5 & 79 \\
\hline 2 & 21 & 76 & 83,6 & 75,41 \\
\hline 3 & 24 & 87 & 95,7 & 71,9 \\
\hline
\end{tabular}

Tingkat perlindungan $=\mathrm{Va} \times 10 \%$

$$
=\mathrm{Va} \times 1,1
$$$$
=87(\text { Sparking Voltage }(\mathrm{kV}) \times 1,1=95,7 \mathrm{kV}
$$

Jadi diperoleh faktor perlindungannya adalah[13] :

$$
\begin{aligned}
\mathrm{FP} & =\frac{T I D_{\text {saluran }}-T P}{T I D_{\text {saluran }}} \\
& =\frac{340-95,7}{340}=71,9 \%
\end{aligned}
$$

\section{KESIMPULAN}

Dengan penempatan arrester sekitar berjarak $200 \mathrm{~m}$ di setiap 4 gawang, diperoleh kenaikan tegangan saat mengalami surja petir dengan kecepatan gelombang 4/10 $\mu$ s, dengan waktu sampai kepuncak $10 \mu \mathrm{s}$, dimana dengan arus surja $65 \mathrm{kA}$ yaitu 4.147,1831 kV, sedangkan untuk arus surja $20 \mathrm{kA}$ dengan penempatan arrester pada tiap gawang saluran distribusi, kecepatan gelombang dan waktu sampai ke puncak yang sama didapatkan kenaikan tegangan yaitu 713 , $385827 \mathrm{kV}$.

\section{REFERENSI}

[1] Erlangga Perdana, 2012 . Buku Panduan Praktis Sistem Proteksi Petir Saluran Distribusi Tenaga Listrik. Bali : PT. PLN ( Persero

[2] Erlangga Perdana; Syarif Hidayat; Reynaldo Zoro , 2014 .Lightning Protection System On Overhead Distribution Line Using Multi Chamber Arrester . Power Engineering and Renewable Energy (ICPERE), 2014 International Conference.

[3] Effendy Sinaga , 2016. Multi Chamber Arrester 20, For Overhead lines Up to $24 \mathrm{kV}$. Jakarta : PT. Preformed Line Products Indonesia.

[4] G. V. Podporkin, 2009. Lightning Protection Of Overhead Lines Rated At 3-35 Kv And Above With The Help Of Multi-Chamber Arresters And Insulator-Arresters . 28 th International Conference on Lightning Protection (ICLP 2006),

[5] Hutahuruk, T.S. 1988. Perhitungan Gangguan Kilat pada Saluran Udara Tegangan Menengah. Bandung : Jurusan Teknik Elektro, Fakultas Teknologi Industri. Institut Teknologi Bandung.

[6] Hutahuruk, T.S. 1989. Gelombang Berjalan dan Proteksi Surja Jakarta : Erlangga.

[7] Hutahuruk, T.S. 1991. Pentanahan Netral Sistem Tenaga dan Pentanahan Peralatan. Jakarta : Erlangga.

[8] Mathieu Zinck , 2016. Application Guide for Streamer's Easy Quench Technology for Overhead Lines Up to $24 \mathrm{kV}$. Russia : Streamer AG.

[9] R. Zoro, 2012. Studi dan Evaluasi Peta Petir Serta Peningkatan Sistem Proteksi Petir pada Jaringan Distribusi 20 kV PT PLN (Persero) Distribusi Bali Area Bali Selatan, Bandung Institute of Technology, Bandung 2013.

[10] R.Zoro ;Tulus Leo , 2015. Multi-Chamber Arrester Study At Tropical Area For 20 Kv Lines Lightning Protection System . Bandung Institute of Technology, Bandung 2015

[11] Rusmana , 2013. “ Studi Pengaruh Pemasangan Kawat Tanah danArrester Untuk Melindungi Saluran Distribusi Tegangan Menengah Akibat Surja Petir . Bali : Teknik Elektro Universitas Udayana 2013.

[12] [NN. 1978. SPLN 7C : Lightning Arrester Part 1 Non Linear ResistorType Arrester For AC System. Jakarta : Departemen Pertambangan dan Energi Perusahaan Umum Listrik Negara. 
[ halaman ini sengaja di kosongkan] 